\title{
THE DOCUMENT MANAGEMENT SYSTEM DIGITAL MATURITY MODEL DEVELOPMENT AND ASSESSMENT IN IN THE ENGINEERING PROCUREMENT CONSTRUCTION (EPC) COMPANY
}

\author{
Bella Anastasya Achita Putri ${ }^{1}$, Prio Utomo ${ }^{2}$, Friska Natalia ${ }^{3}$ \\ \{bella.anastasya@student.umn.ac.id ${ }^{1}$, prio.utomo@umn.ac.id ${ }^{2}, \underline{\left.\text { friska.natalia@umn.ac.id }{ }^{3}\right\}}$ \\ Technology Management Dapartement, Multimedia Nusantara University, ${ }^{2,3}$
}

\begin{abstract}
In the engineering, procurement, construction (EPC) industry documents it's very important in business processes. This can be advantageous because it can reduce the loss and the delay in the communication process with clients, vendors and stakeholders. So that the most effective management system is needed to be able to manage various information in the form of documents or files that can be stored so that they can be reused for other business processes. To be able to overcome this requires the application of an Electronic Document Management System (DMS). In this paper, we will explain how to assess the digital maturity of a company. In addition, it explains how the EPC industry can carry out digital transformation in conducting the assessment using a questionnaire survey and conducting interviews. EPC companies need to create an Electronic Document Management System because all types of data can be uploaded into this DMS application on a web basis. Software applications that capture, store and archive documents.
\end{abstract}

Keywords: Document Management System, Digital Transformation, Enterprise Content Management

\section{Introduction}

In this study raised the EPC industry. This becomes important which can be seen from the good economic growth. This can be shown by investors having confidence in the increasing level of consumer demand, specifically investors can open new factory facilities or increase manufacturing capacity. So this is a prospect for the EPC industry which can be proven by the presence of factory relocation from China so that factory construction in Indonesia increases.

In this research, the issue to be raised is document management in the EPCC industry. This is very important because the process carried out in the industry consists of four jobs, namely Engineering, Procurement, Construction, Commissioning of each of these processes, both technical and non-technical documents are one of the most important things. Each process / stage has a large number and has various types. This takes a long time to find and organize documents properly. This is one of the problems that arise in this industry.

Currently the document management process is assisted by document control whose task is to store, search for documents and provide letter numbers. However, this is quite difficult for a document control because the documents handled are not a few from various divisions and from all users.

In the last decade or so research has focused on providing a biblical overview of the stages in the use of document management systems in the construction industry. In this study showed a lack of good document and process management skills. Describes that especially its information management document management will be more efficient by using an Electronic Document Management System [1].

The purpose of this research is to build a system in this case to assist document management in the EPC industry. One of them is by creating an Electronic Document Management System (DMS). These temporary papers and various electronic files allow safe accessibility in times of need. This Electronic Document Management System has five basic components, namely imaging (capturing and importing), archiving and storage, retrieval and distribution, business process automation, mobile security or remote access. With this system management, it will result in good data management by capturing documents, storing, indexing and retrieving documents. This can increase access to records via users from the admin where they can easily find and retrieve the required documents [2] productivity, supporting the go green movement because it is paperless, and increasing coordination between the ICT division and projects to work together in building this program [3].

There are several challenges in implementing the Electronic Document Management System that need to be considered, first, the change in the work process that starts from manual to digital, becomes a challenge when it comes to changing employee work habits or culture from manual to digital collar. Second, challenges in security.

This is because a web-based DMS is likely to have a Web attack. Third, collaboration between departments. Because this is not only designed / built by the IT department but involves other departments. 
The benefits for the EPC industry are that there is no lag in ideal conditions in carrying out a business process in an industry, carrying out processes related to documents and carrying out digital transformations, automating tasks and increasing process efficiency, in order to improve good communication between departments and the entire organization. . More focus on business requirements rather than filing and looking for documents, minimize document loss, minimize document control errors, and adjust numbering automatically [4].

Whereas the opportunity for the EPC industry to carry out this transformation is to reduce the cost of sending mail, be able to change the concept of document management from manual to digital, users get the right communication on time without having to wait for control documents, minimize costs and risks associated with complicated processes., allows staff to work more efficiently, reduces delays in processing payments to vendors / stakeholders and can help campaign go green through paperless, long-term savings.

\section{Literature Review}

\subsection{EPCC Industry}

The EPCC industry stands for Engineering, Procurement, Construction, and Commissioning. This industry is to design / design the system to be built, procure / purchase goods for development needs and continue with building / carrying out construction that has been designed. An engineering consultant / contractor company that is responsible for an EPCC (Engineering, Procurement, Construction, and Commissioning) activity is commonly called the EPC Company [5].

EPC characteristics in each Engineering, Procurement, and Construction activity have their respective documents. Both technical and non-technical. This document is of course very important in carrying out these three activities.

In the EPCC industry an Electronic Document Management System (DMS) is of course necessary and very important in the EPCC industry. This is due to the workflow carried out in this industry, namely the client conducts an auction process to a suitable contractor for a project and the owner creates a concept \& conducts a feasibility test. After that the EPC Contractor will start making Front End Engineering Design (FEED), continue to make Detailed Engineering Design (DED) (Engineering), make material purchases (Procurement), continue to carry out construction (Construction), after completing the tests before being submitted to the owner (Commissioning) [6]. Lastly, do the surgery right away. With this EPCC workflow, documents are one of the most important things in this activity because they support work such as FEED and DED in the form of documents as a reference for carrying out construction, invoices and work contracts in purchasing materials (Procurement), and reports on during construction.

\subsection{Electronic Document Management System}

This Electronic Document Management System (DMS) focuses on document management. DMS is a system or process used to capture, track and store electronic documents such as PDF, file word, digital images [7]. This activity has the function of combining document and content retrieval, workflow and document repositories, output systems to information retrieval (documents).

Document management is important for the company because the function of this DMS is to become a storage and information warehouse. This can reduce the risk of documents owned by the company, namely errors and redundancy that are damaged and lost. This is because the company still keeps paper documents so that it requires more physical space. With this DMS can minimize this.

\subsection{Digital Maturity Model}

Digital Maturity Model (DMM) is a measure of how ready an organization is to transform digitally. This DMM consists of several dimensions and sub dimensions, which can be seen as a group of digital capabilities. In carrying out a digital Electronic Document Management System (DMS) transformation to see digital readiness, you can use the Enterprise Content Management Model (ECM) in one of the journals entitled Assessing The Functionality Of The Enterprise Content Management Maturity Model which was created from the collaboration of several companies [8].

In doing this, using this ECM because DMS is one of the generations in it. The ECM Maturity model aims to provide a structured framework that can form a map for creating enterprise content management in the overall context. The application of this model can be done to conduct audits, assessments and explain the current state of the company.

The ECM Maturity Model has 13 dimensions in three categories, namely humans, information and systems[9]. In the human category there are sub dimensions of Business enterprise, IT, process, and alignment. The information category contains the content/metadata sub dimensions, depth, governance, re-use, findability. Whereas in the system category, namely Scope, Breadth, security, usability. In ECM, it can be seen from the indicators to 
measure the dimensions and sub-dimensions there are 5, namely Unmanaged (not managed), Incipient (planned), Formative (already made), Operational (already used / implemented), Proactive (already actively used / used frequently) [8].

To determine the maturity of the company to collect data using a questionnaire and conduct interviews with several respondents. In data collection, questionnaires were distributed to 30 respondents in the project to be carried out by the DMS pilot project. In the results it is at level 3. This shows formative (it has been made) but in fact the Cisem project does not have this DMS. By looking at these results an interview was conducted to prove if DMS was needed and this system had to be built immediately. In general, interviews have shown that manual and paper-based DMS is better known in this company. However, the implementation of this manual system can cause delays and difficulties in business processes and due to document loss. However, with the electronic DMS plan, the company is pushing for the implementation of this web-based DMS application.

\section{Methodology and Data Analysis}

\subsection{Scientific Methodology}

The method in collecting the data is by using a questionnaire survey. The main purpose of the survey is to capture the initiative and challenge and investigate the measurement of digital maturity in EPC companies. This questionnaire was designed to comply with the use of the Electronic Document Management System (DMS). It is expected that this questionnaire will seek opinions from managers to employees about DMS. The questionnaire will be distributed to employees at the company and distributed according to their respective disciplines or positions. However, the number of respondents cannot be determined because in fact in this case it is possible that only one division which is associated with DTP will be created.

In this questionnaire contains 23 questions covering three dimensions and eight sub dimensions. By using a Likert scale of 1-5 but in accordance with the ECM indicators, namely unmanaged, incipient, formative, operational, and proactive. Respondents in the study were the cisem project, the ICT division, the Quality Assurance / Quality Control QA / QC division, the document control division. With the number of respondents as many as 30 people. This questionnaire is distributed via Google Form from 24-30 April 2020. However, before it is distributed, testing is carried out, namely the validity test and the reliability test. In addition to conducting surveys through questionnaires, researchers also conduct interviews to support the results of the questionnaire and see the digital maturity of projects that will carry out digital transformation.

\subsection{Data Analysis}

After completing the survey, data analysis is carried out to determine the results of the company's condition assessment using this ECM Maturity Model. The analysis was carried out using descriptive analysis. Descriptive analysis method is a method by collecting data in accordance with the actual data then the data is compiled, analyzed and processed to be able to show the existing problems. This is done to get a systematic, factual and accurate picture of the facts and properties as well as the relationships regarding indicators in the variables in the study[10].

Performing this descriptive analysis, one of which determines the conclusion criteria for each question. the determination of criteria is the level / indicator of the ECM Maturity Model [8]. By using the value range with the formula of the highest value minus the lowest value divided by 5 . Descriptive analysis will produce measurement results of the respondent's profile and the available variable-variable measurement results.

\section{Research Results and Discussion}

Results and discussion of the DMM that have been carried out through a survey with 30 respondents to see the current conditions. The results of these analysis show right that the company is in level 3 are Formative. Then, afterwards to see the conditions that will come out of 30 respondents were pursed into five respondents to do live interviews.

The results of the interviews were directly translated through a discussion of the GAP analysis between current conditions and conditions in the future. The results of this interview highlight that to implement a successful electronic DMS in their opinion.

From the results of the interview, it can be seen that there is a gap in the project in the human dimension in the sub-dimension of Business Expertise, the position at level 1, namely ignorance of the value and role of DMS and in the future at level 3, namely the existence of communication between the project team and key stakeholders of ECM business value. In sub dimensions IT position at level 1 No of its management of Electronic Document Management Systems and workflow formal, future will come at level 2 Implement a system for document management and its workflow. In the process sub dimension pad a current position at level 1 there is no management of its Electronic 
Document Management System and workflow formal, in the future that will come at level 3 modeling between department beginnings of the process to automate document management.

While the dimensions and sub dimensions Governance information at the level of 1 there are no policies and procedures or SOPs applicable, in the future will come at level 3 developing the governance structure and the modification procedure information. In sub dimensions reuse is at level 4 Document reused throughout the system and channel in this case also apply the reuse of business processes, in the future will come at level 5 All documents reused across systems and channels. Findability sub dimension at level 1 Employees spend excessive time searching using various internal search engines. In this case the search manually, in the future will come at level 3 Rationalization of technology to search, analyze search logs. Recently Reviewed sub dimensions system security dimension is currently at level 1 No security applied to the document management in the future will come at level 3 formal project initiated to address the gaps and carry out redundancies. In sub dimensions usability are at level 1 Lack of Electronic Document Management System in doing so into consideration the use of the system, and in the future will come at level 3 make some initiatives persona scenario and engineering users / user.

With the implementation of this DMS, the benefits and savings, of course, can be seen from several activities, namely the activity of printing and photocopying documents (document reuse), which can be about $26 \%$ efficient, storage \& findability activities can be efficient by about $50 \%$ and delivery activities. About $50 \%$ saving of documents, of course this can improve the document management process carried out by the company.

So that by looking at this GAP analysis, an Electronic Document Management System can be built that can reach the desired level. By building an Electronic Document Management System, users will be able to store independently without the help of document control, search for documents independently and do not require a long / faster time. Apart from time, this can be done anywhere and anytime and connected to the internet network.

By looking at the GAP analysis above, there is a solution to be applied, namely the implementation of an Electronic Document Management System. This web-based application will be divided into two categories, namely admin and user. Both have different ways of working. In the admin category, the admin is in charge of administering the things in the application. Besides that, he served as a person who monitors documents. Meanwhile, the user cannot do admin work. The user is only a user who can perform searches, save documents, get document numbers automatically and search for documents. This before (Current) and after (Future) implementation of Document Management Document (See Appendix 1).

This application consists of seven pages, namely Login, Home, Save Document, Find Document, Document Number, User Management and Settings. On the home page there is some information, namely the number of documents, documents shared, the number of registered users, information about EDMS and data about documents in accordance with their division. While on the save document page, you can add documents, edit and delete documents. The following shows the Home page and Save Document as below:
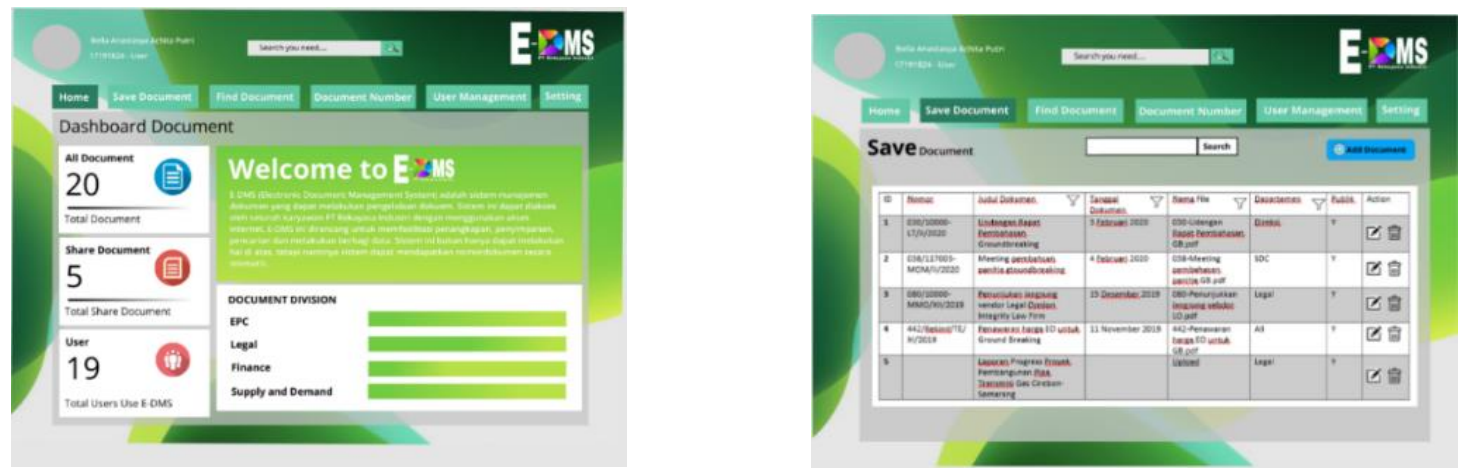

Fig. 1. Home Page and Save Document Page of E-DMS

After that, there is a find document and document number page. On this page the user and admin can search, retrieve (download) documents. While on the document number page the admin will provide a number for the user and the user will get a document number automatically. Here is how it looks: 

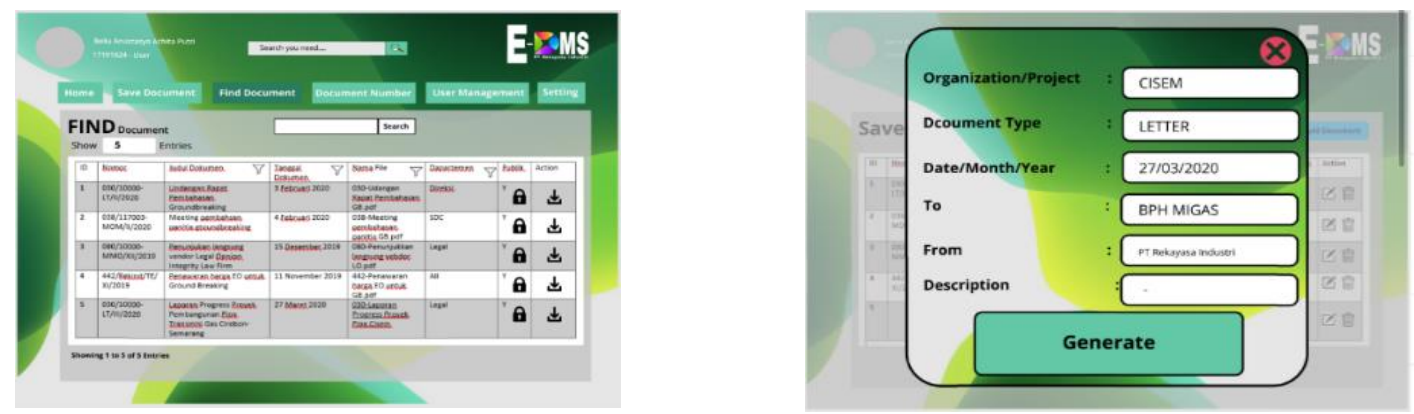

Fig. 2. Find Document page and page requirement document number E-DMS

In addition, there is a user management and settings page. User Management can register user, edit, and delete registered user data. While on the settings page the admin can register. User can see what dapartemen are registered and see organization code. Here is how it looks:
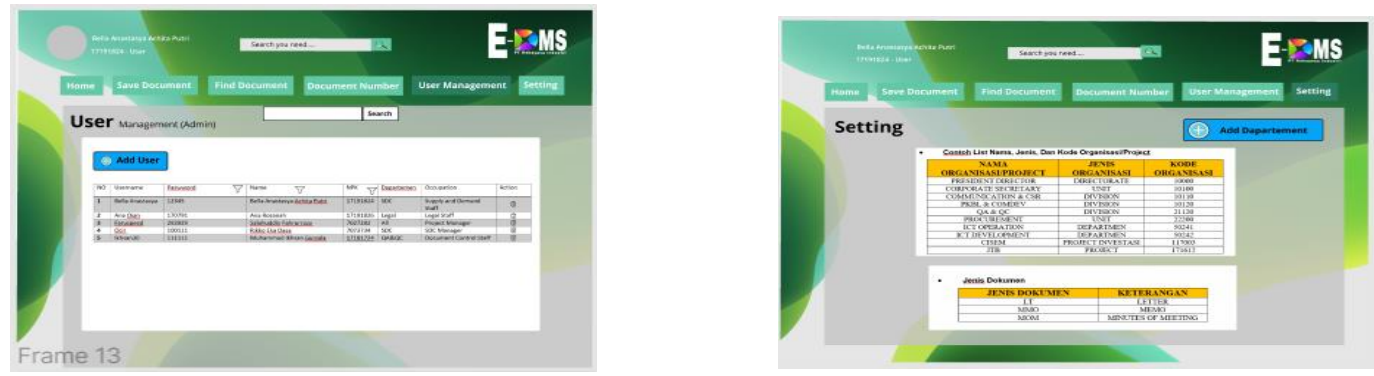

Fig. 3. Page User Management (Admin) and user settings E-DMS PT

\section{Summary}

With the existence of digital transformation, namely the creation of this system management document, it can provide benefits for the company, namely from an economic, environmental and social perspective. Increase employee productivity, increase time and cost efficiency in document management, increase collaboration within the company between divisions and projects, and automate business processes. In addition, by implementing a document management system, savings can be made in document management activities. In financial calculations it can be concluded that the savings in this implementation are $46 \%$ of the expenditure on document management for 1 year.

However, there is a challenge if you want to carry out this transformation, which is to change the employee culture from activities that are usually done manually to digital. This allows researchers to create a system that is userfriendly and easy to operate. It can also enhance the organizational or project learning process

\section{Implications / Limitations and Suggestions for Further Research}

The shortcomings and limitations of this digital transformation are the lack of respondents in the project because there are less than 20 employees, so researchers try to find respondents outside the project but fall into the criteria. Nevertheless, the author able to acquire sufficient data for this research. The limitations of conducting discussions due to the Covid-19 pandemic conditions have hampered the process of approaching decision makers, in this case the company. Time limitation is also one of the obstacles for researchers to do writing figures perfectly. 


\section{Reference}

[1] C. C. Wang and P. Jim, "A Review on Document and Information Management in the Construction Industry: From Paper-based Documents to BIM-based Approach," Proc. 2012 Int. Conf. Constr. Real Estate Manag., no. October 2012, pp. 369-373, 2012.

[2] R. Shaikh and M. Sasikumar, "Electronic Document Management System Implementing Internet of Things (IoT)," Procedia Comput. Sci., vol. 45, no. C, pp. 493-498, 2015, doi: 10.1120/jacmp.v15i6.486.

[3] M. Greco, M. Grimaldi, and M. Hanandi, "How to select knowledge management systems: A framework to support managers regular paper," Int. J. Eng. Bus. Manag., 2013, doi: 10.5772/56003.

[4] A. Blok, "The EPC contractors answer to current market challenges."

[5] PT.Rekayasa Industri, "Laporan Keberlanjutan Sustainability Report," 2018.

[6] PT.Berkat Manunggal Jaya, "Perusahaan EPC," 2019. [Online]. Available: http://bmj.co.id/tentanggenset/perusahaan-epc/. [Accessed: 20-Dec-2019].

[7] IBM, "Document management," Process Engineering (London), 2020. [Online]. Available: https://www.ibm.com/topics/document-management.

[8] S. Katuu, "The Utility of Maturity Models-The ECM Maturity Model within a South African context," Capab. Assess. Improv. Work. IPRES, 2013.

[9] T. Pelz-Sharpe, Alan; Durga,Apoorv; Smigiel, David; Hartman, Erik; Byrne, "ECM Maturnity Model," vol. 1.0, p. 38, 2009.

[10] P. D. Sugiyono, metode penelitian kuantitatif, kualitatif,dan R\&D. 2016. 


\begin{tabular}{|c|c|c|c|c|c|}
\hline \multicolumn{6}{|c|}{ Comparison Table Using Document Management System } \\
\hline No. & Activity & Before & After & Financial impact & Non financial impact \\
\hline 1 & $\begin{array}{l}\text { Print and Photocopy } \\
\text { of Documents } \\
\text { Activities }\end{array}$ & Using 10 HVS Paper Boxes & Only use 5 HVS Paper Boxes & $\begin{array}{l}\text { can reduce the cost of purchasing HVS paper by } \\
50 \% \text { the usual costs }\end{array}$ & $\begin{array}{l}\text { Can reduce the amount of paper used, support } \\
\text { the campaign to go green }\end{array}$ \\
\hline 2 & $\begin{array}{l}\text { Document Retention } \\
\text { Áctivity }\end{array}$ & \begin{tabular}{|l|} 
Using 2 Cabinets and 12 \\
Bantexes, the documents \\
were given to the control \\
documents and kept in the \\
cupboard
\end{tabular} & $\begin{array}{l}\text { Using the database on the } \\
\text { DMS, users can do this } \\
\text { through the DMS website }\end{array}$ & $\begin{array}{l}\text { Can reduce the cost of purchasing storage, namely } \\
\text { cabinets and bantex by } 50 \% \text { of the usual costs }\end{array}$ & $\begin{array}{l}\text { Can reduce hardcopy storage, no need to } \\
\text { provide space to put a document cabinet }\end{array}$ \\
\hline 3 & $\begin{array}{l}\text { Control Document } \\
\text { Activity }\end{array}$ & $\begin{array}{l}\text { Must serve the user for } \\
\text { storage and search }\end{array}$ & $\begin{array}{l}\text { Document Control is in } \\
\text { charge of being the admin } \\
\text { and maintaining the DMMS } \\
\text { systern }\end{array}$ & $\begin{array}{l}\text { Does not reduce the cost of paying salaries, but can } \\
\text { be calculated through the time spent helping users } \\
\text { about } 50 \% \text { of the time normally used }\end{array}$ & $\begin{array}{l}\text { Users no longer need to wait for control } \\
\text { documents to perform searches, document } \\
\text { storage, and can be used as admin }\end{array}$ \\
\hline 4 & File Search Activity & $\begin{array}{l}\text { In searching manuallyit } \\
\text { takes } 1-2 \text { days }\end{array}$ & $\begin{array}{l}\text { With the DMS system, you } \\
\text { can search in just a matter of } \\
\text { hours or minutes }\end{array}$ & $\begin{array}{l}\text { Can reduce the time in file searches perforned by } \\
\text { control documents. Can be converted into fees, } \\
\text { namely } 50 \%\end{array}$ & $\begin{array}{l}\text { Can search quickly, users can do it } \\
\text { independently without the help of control } \\
\text { documents }\end{array}$ \\
\hline 5 & $\begin{array}{l}\text { Document Delivery } \\
\text { Activity }\end{array}$ & $\begin{array}{l}\text { Delivery is done via courier, } \\
\text { Gosend, to delivery services }\end{array}$ & $\begin{array}{l}\text { Can be done via DMS by via } \\
\text { enail, so as to cul shipping } \\
\text { costs }\end{array}$ & $\begin{array}{l}\text { Can reduce shipping costs by } 70 \% \text { from the costs } \\
\text { usually incurred vila courier, gosend to courier } \\
\text { services }\end{array}$ & $\begin{array}{l}\text { Can be done digitally via email or short } \\
\text { message }\end{array}$ \\
\hline 6 & $\begin{array}{l}\text { Invoice Processing } \\
\text { Activity }\end{array}$ & $\begin{array}{l}\text { Approva was done } \\
\text { manually and it took more } \\
\text { than a day so that the } \\
\text { payment process was } \\
\text { dolsuad }\end{array}$ & $\begin{array}{l}\text { Can reduce approval time so } \\
\text { that it is faster and there are } \\
\text { no delays in the payment } \\
\text { process }\end{array}$ & $\begin{array}{l}\text { Can reduce invoice processing time. If converted } \\
\text { into costs, it can save } 50 \%\end{array}$ & $\begin{array}{l}\text { Can speed up the approval process so that the } \\
\text { payment process through the finance division } \\
\text { can be done as soon as possible. So as to } \\
\text { minimize delays in the payment process }\end{array}$ \\
\hline 7 & $\begin{array}{l}\text { Missing Document } \\
\text { Activity I Human Error }\end{array}$ & $\begin{array}{l}\text { There was a loss of } 2 \\
\text { document cabinets and } \\
\text { errors in filing documents }\end{array}$ & $\begin{array}{l}\text { The possibility of losing will } \\
\text { be reduced or even non- } \\
\text { existent because it has been } \\
\text { done in the system }\end{array}$ & Can reduce the cost of lost documents by $50 \%$ & $\begin{array}{l}\text { Documents that are stored safely are } \\
\text { maintained so that the incidence of document } \\
\text { loss is reduced or even non- } \\
\text { existent. Documents that have been saved also } \\
\text { have minimal errors because an admin can }\end{array}$ \\
\hline
\end{tabular}

Appendix. 1. 